\title{
Natural Killer Cell Viability After Hyperthermia Alone or Combined with Radiotherapy with or without Cytokines
}

\author{
TENHO HIETANEN ${ }^{1}$, MIKA KAPANEN ${ }^{2,3}$ and PIRKKO-LIISA KELLOKUMPU-LEHTINEN ${ }^{1,2}$ \\ ${ }^{1}$ Department of Oncology, Faculty of Medicine and Life Sciences, University of Tampere, Tampere, Finland; \\ Departments of ${ }^{2}$ Oncology and ${ }^{3}$ Medical Physics, Tampere University Hospital, Tampere, Finland
}

\begin{abstract}
Background: The effects of hyperthermia and irradiation, alone and in combination, on natural killer (NK) cell viability were investigated in vitro. The roles of interleukin-2 (IL-2) and interferon (IFN) $\alpha, \beta$ and $\gamma$ in rescuing $N K$ cells from hyperthermia and irradiation were studied. Materials and Methods: Non-selected NK cells were used as effector cells and $K-562$ cells as target cells. NK and $K-562$ cells were treated at 37 to $45^{\circ} \mathrm{C}$ for 0 to $180 \mathrm{~min}$. The cells were irradiated at room temperature using single doses from 0 to $60 \mathrm{~Gy}$. Recombinant IL-2 at 100 to $450 \mathrm{U} / \mathrm{ml}$ and recombinant IFN $\alpha, \beta$ and $\gamma$ at 1,000 U/ml were used for different periods of time. NK cell viability was measured by intracellular adenosine tri-, and diphosphate (ATP, ADP) levels via luminometer, trypan blue exclusion and propidium iodide (PI) staining. Binding capacity of NK effector cells to target K-562 cells was also microscopically assessed. Results: Thermal treatments between 37 and $41^{\circ} \mathrm{C}$ did not significantly affect the ATP levels of NK cells. Between $41^{\circ} \mathrm{C}$ and $42^{\circ} \mathrm{C}$, ATP levels significantly decreased, whilst there was an insignificant reduction up to $45^{\circ} \mathrm{C}$. At $42^{\circ} \mathrm{C}$ or higher, no recovery was detectable. At $42^{\circ} \mathrm{C}$, the ATP level of $N K$ cells rescued by $I L-2$ were significantly higher than those of controls at $37^{\circ} \mathrm{C}$. IFN $\alpha, \beta$ and $\gamma$ had no significant effects. A combination of heating at $42^{\circ} \mathrm{C}$ and irradiation at $20 \mathrm{~Gy}$ significantly reduced the ATP levels $(p<0.001)$ more than heating and irradiation alone. At $42^{\circ} \mathrm{C}, I \mathrm{~L}-2$ abolished the reduction of ATP levels by heating and irradiation. This effect was dependent on heating time and irradiation dose. The ATP/ADP ratio did not significantly change when NK
\end{abstract}

This article is freely accessible online.

Correspondence to: Tenho Hietanen, Department of Oncology, Faculty of Medicine and Life Sciences, University of Tampere, PB 100 FI-33014 Tampere, Finland. Tel: +358 442314673, e-mail: tenho@hietanen.net

Key Words: Natural killer (NK) cells, viability, ATP, ADP, hyperthermia, irradiation, recovery, IL-2, IFN. cells were heated for different times at $42^{\circ} \mathrm{C}$. Thermal treatment of target $K-562$ cells at temperatures from 37 to $45^{\circ} \mathrm{C}$ reduced the number of $N K$ cells binding $K-652$ cells. Conclusion: In vitro, $N K$ cell viability was strongly reduced between $41^{\circ} \mathrm{C}$ and $42^{\circ} \mathrm{C}$. At $42^{\circ} \mathrm{C}$, the combination of irradiation and thermal treatment reduced the ATP levels in $N K$ cells. However, IL-2 restored cell viability depending on thermal and radiation doses.

Natural killer (NK) cells belong to the family of innate lymphoid cells. They are important effector cells (1), with germline-encoded transmembrane pattern recognition receptors for pathogens and damaged self-components (2). They can recognize cells with altered or lack of selfstructures, such as major histocompatibility complex (MHC) class I molecules; these cells include cancerous, microbially infected, chemically or physically altered and injured cells. NK cells can directly kill them or induce their apoptosis (3, 4). NK cells can also eradicate tumour cells. Thus, they are important in tumour immunosurveillance $(1,5)$ and are used to treat cancer $(1,6)$.

Currently, cancer is treated using therapies such as surgery, radiation, chemotherapy, hormonal treatment, targeted therapy, immunological therapies, hyperthermia and hypothermia. These treatment modalities are often combined with each other $(7,8)$. They affect activation and inhibition of NK cells and cytotoxicity against tumour cells in various manners $(9,10)$.

As a clinical treatment, hyperthermia has been used alone $(11,12)$, and in combination with radiotherapy $(13,14)$. Hyperthermia is defined in different ways. According to the Kadota Fund International Forum in 2004, it is a modest elevation of temperature in the range of $39-45^{\circ} \mathrm{C}$. Higher temperatures are considered thermal ablation $(7,15)$. Feverrange temperatures are defined as $38.3^{\circ} \mathrm{C}$ or more and high fever as that at $39.5^{\circ} \mathrm{C}$ or more $(16,17)$. Thermal ablation occurs at temperatures from 48 to $60^{\circ} \mathrm{C}(18)$.

Hyperthermia in the range of 40 to $47^{\circ} \mathrm{C}$ has numerous effects on living cells in temperature-, time- and dosedependent manners (19). It can cause many macromolecular 
changes, including unfolding of proteins and protein aggregation. Proteins within the nucleus are critical for normal transcription, replication, and repair of deoxyribonucleic acid (DNA). DNA damage is not primarily due to direct heat-induced DNA alterations but is secondary to the effects of heat on proteins involved in DNA replication, chromosome segregation, and DNA repair. These events can lead to cell death either by hyperthermia-induced apoptosis or by a mitotic catastrophe secondary to alterations in DNA-supporting proteins. Most cell lines die though a combination of these death processes (19).

In vivo, $\mathrm{NK}$ cell cytotoxicity and their recruitment to tumour sites are increased by fever-range hyperthermia (20, 21 ), whereas in vitro, they are reduced in a heating-time- and temperature-dependent manner (22-24).

In the 1980s, Jonsson and colleagues studied the effects of hyperthermia on the adenosine triphosphate (ATP) pool in human mononuclear leucocytes. They showed that the ATP pool was reduced by moderate hyperthermia $\left(42.5^{\circ} \mathrm{C}\right.$ for 45 min) (25), whereas another group did not observe any effects (26). In studies of hyperthermic heart failure, ATP degradation by mitochondria and reduced ATP production and hydrolysis were observed at high temperatures $\left(43.5^{\circ} \mathrm{C}\right)$ (27). In addition, Eguchi et al. demonstrated that the intracellular ATP level is a determinant of the incidence of cell death, either by apoptosis or necrosis (28).

Previously, we reported the effects of hyperthermia and irradiation on cytotoxicity of NK cells (29). In the present study, we explored the effects of hyperthermic temperatures on NK cell viability as measured by ATP level. Furthermore, we studied the combined effects of hyperthermia and irradiation on the intracellular ATP content of NK cells. We also investigated the ability of interleukin-2 (IL-2) and interferons (IFN) to abolish changes induced by hyperthermia alone and hyperthermia combined with irradiation.

\section{Materials and Methods}

NK cell enrichment. For NK cell enrichment, we used buffy coat samples obtained from the Finnish Red Cross Transfusion Laboratory, with permission of the Ethical Committee of the Finnish Red Cross Blood Service (customer number 6129, approval number 331/2013, tutkijaluvat@veripalvelu.fi) in accordance with Finnish law.

We isolated non-selected NK cells by the method previously described by Hietanen et al. [method II; (30)]. Briefly, peripheral blood mononuclear cells were isolated by a Ficoll-Paque gradient, plastic and nylon wool adherence and a discontinuous Percoll gradient. The yield, purity, viability, cytotoxicity and radiation sensitivity of the enriched NK cell populations were described in a previous report (30).

Target cells and culture conditions. Cells of the erythroleukaemia cell line K-562 (LGC Standards GmbH, Wesel, Germany) (31) were used as the target cells. Mycoplasma tests were performed at the time of experiments. The cells were grown in RPMI 1640 medium (Orion Diagnostica, Espoo, Finland) with $10 \%$ temperatureinactivated foetal calf serum (Flow Laboratories, Irvine, Scotland, UK), $0.3 \mathrm{~g} / 1 \mathrm{~L}(+)$-glutamine (Fluka, Buchs, Switzerland) and 20 $\mathrm{mg} / \mathrm{ml}$ gentamicin (Flow Laboratories).

Thermal treatment. The thermal treatment of effector NK and target K-562 cells was described previously in detail (29). In brief, cells were suspended in $1 \mathrm{ml}$ of medium and incubated at different temperatures in a water bath or an incubator in a humidified atmosphere of $5 \% \mathrm{CO}_{2}$. The temperatures used ranged from 37 to $45^{\circ} \mathrm{C}$, and heating periods were typically from 0 to $180 \mathrm{~min}$. In recovery experiments, the cells were incubated at $37^{\circ} \mathrm{C}$ for 0 to 72 $\mathrm{h}$ after heating.

Irradiation. The enriched NK cell populations were gammairradiated as described previously (32). In brief, we used a ${ }^{137} \mathrm{Cs}$ device (GAMMACELL 2000, Mølsgaard, Denmark) at a dose rate of $4.1 \mathrm{~Gy} / \mathrm{min}$ at room temperature $\left(20^{\circ} \mathrm{C}\right)$. The NK cells were irradiated at single doses ranging from 0 to $60 \mathrm{~Gy}$.

IL-2 and IFN treatment. We used recombinant IL-2 (Jansen Biochimica, Beerse, Belgium), recombinant IFN- $\alpha 2 b$ (ScheringPlough, Kenilworth, NJ, USA), recombinant IFN- $\beta$ (Kyova Hakko Kogyo Co., Ltd., Tokyo, Japan), and recombinant IFN- $\gamma$ (Genentech, San Francisco, CA, USA) as reported previously (32). In brief, NK cells were incubated at $37^{\circ} \mathrm{C}$ with $\mathrm{IL}-2$ at a concentration of 100 or $450 \mathrm{U} / \mathrm{ml}$, and incubation times were from $72 \mathrm{~h}$ to $120 \mathrm{~h}$. Incubation time for IFN $\alpha,-\beta$ and $-\gamma$ was $72 \mathrm{~h}$ at concentrations of $1,000 \mathrm{U} / \mathrm{ml}$.

Controls were treated in the same way without cytokines.

ATP and adenosine diphosphate (ADP). The ATP and ADP measurements were performed as described previously (32). In brief, ATP and ADP contents of heated NK cells irradiated or not, with or without treatment with IL-2 or IFNs were measured by commercial kits from LKB Wallac (Turku, Finland) according to the manufacturer's instructions and using an LKB Wallac 1251 luminometer. ATP/ADP measurements were performed immediately after thermal treatment or irradiation at room temperature and up to $72 \mathrm{~h}$ after the thermal treatment in recovery studies. The ATP and ADP contents of NK cells were expressed as a percentage of the controls at $37^{\circ} \mathrm{C}$.

Trypan blue exclusion and propidium iodide (PI) methods for viability assessment. We also measured the viability of thermaltreated/irradiated NK cells using trypan blue exclusion, propidium iodide (Sigma Chemical Co., St Louis, MO, USA) and flow cytometric methods as described previously (33).

Conjugate assay. The binding capacity of effector NK cells to target $\mathrm{K}-562$ cells was measured by a conjugate assay (34). After hyperthermic treatments, $1 \times 10^{5}$ heated or unheated NK cells were mixed with $1 \times 10^{5}$ heated or unheated K-562 cells in $1 \mathrm{ml}$ of medium for $10 \mathrm{~min}$ at $37^{\circ} \mathrm{C}$. The suspension was centrifuged for $5 \mathrm{~min}$ at a speed of $130 \times g$, gently resuspended, and $0.2 \mathrm{ml}$ of the reconstituted suspension was cytocentrifuged and stained with Giemsa stain. At least $200 \mathrm{NK}$ cells were counted and the percentage of NK cells binding to K-562 (rosettes) cells was calculated. 


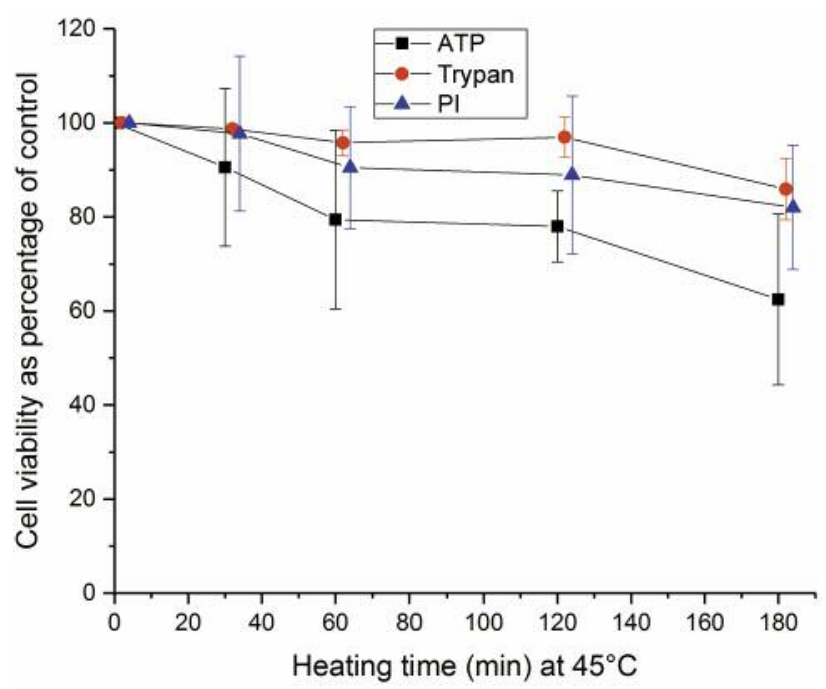

Figure 1. The suitability of adenosine triphosphate (ATP), trypan blue exclusion (Trypan) and propidium iodide (PI) in measuring the damage to natural killer (NK) cells by heat. NK cells were heated for 0, 30, 60, 120 and 180 min at $45^{\circ} \mathrm{C}$, and viability was measured by these methods. The error bars represent the standard deviation of the experiments $(n=3-7)$. There were no statistically significant differences between the effects of these substances $(p=0.121)$.

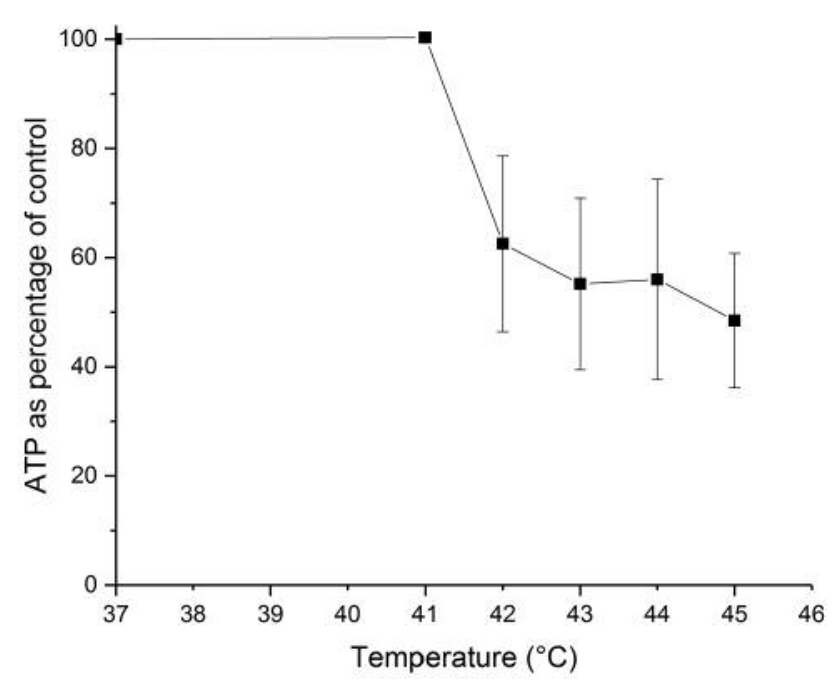

Figure 2. Adenosine triphosphate (ATP) content of natural killer (NK) cells at different temperatures. The NK cells were incubated for $180 \mathrm{~min}$ at temperatures from 37 to $45^{\circ} \mathrm{C}$. The error bars represent the standard deviation of the experiments $(n=4-38)$. A significant reduction in ATP level was observed between 41 and $42^{\circ} \mathrm{C}(p=0.020)$.

Data presentation and statistical analyses. The results of the ATP assays were expressed as a percentage of untreated, i.e. unheated/non-irradiated or lacking IL-2 or IFN treatment, control

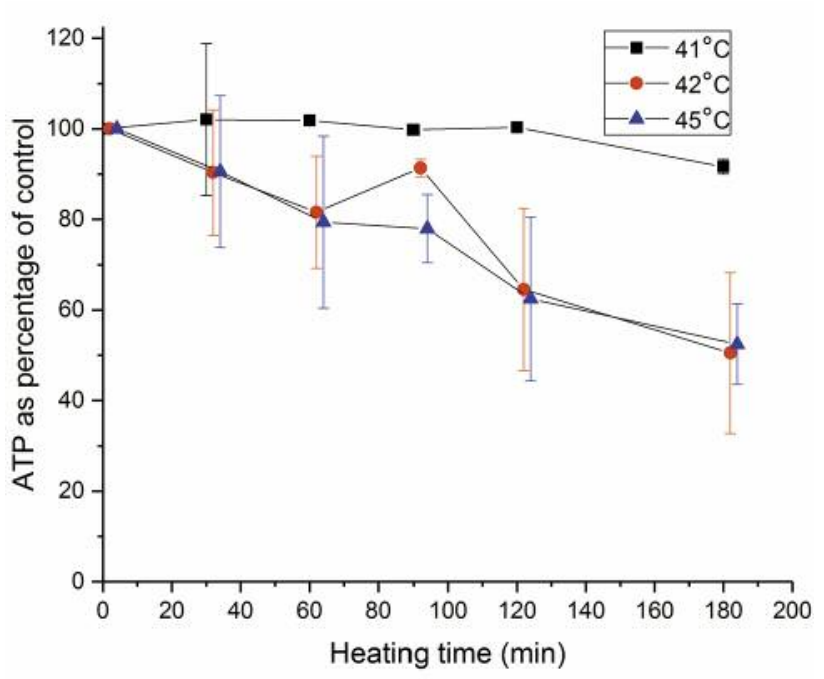

Figure 3. The effects of different heating times on adenosine triphosphate (ATP) content of natural killer (NK) cells at $41^{\circ} \mathrm{C}, 42^{\circ} \mathrm{C}$ and $45^{\circ} \mathrm{C} . \mathrm{NK}$ cells were heated for 30,60, 90, 120 and $180 \mathrm{~min}$, and ATP was measured. The error bars represent the standard deviation of the experiments $(n=2-38)$. A significantly greater reduction of ATP was visible at $42^{\circ} \mathrm{C}$ than at $41^{\circ} \mathrm{C}(p=0.048)$.

NK cells at $37^{\circ} \mathrm{C}$. Every value represents the mean of several independent tests from different donors and data are presented as the mean \pm standard deviation (S.D.). We used SPSS 15.0 software (SPSS Inc., Chicago, IL, USA) for data analysis. For normally distributed data, we used analysis of variance (ANOVA) with Bonferroni correction to test significance of differences between the effects of the different temperatures and heating times with and without IL-2 and irradiation. For analyses of non-normally distributed data, the Kruskal-Wallis test and the Mann-Whitney $U$ test were applied. A $p$-value of 0.05 or less (two-sided) was considered significant.

\section{Results}

Firstly, we compared the suitability of three different methods to assess the effects of heat on NK cell viability. We used intracellular ATP content, the trypan blue method and propidium iodide staining. We heated NK cells at $45^{\circ} \mathrm{C}$ for 0 to $180 \mathrm{~min}$ (Figure 1). The results from different methods did not differ significantly $(p=0.121)$. The selected methods equally well reflect the effects of heat on NK cell viability. The ATP method was the most convenient to perform, and it was selected for further experiments. In addition, ATP reflects the energy level of NK cells.

Effect of temperature and heating time on intracellular ATP content of $\mathrm{NK}$ cells. We studied the effects of different temperatures ranging from 37 to $45^{\circ} \mathrm{C}$ on the intracellular 


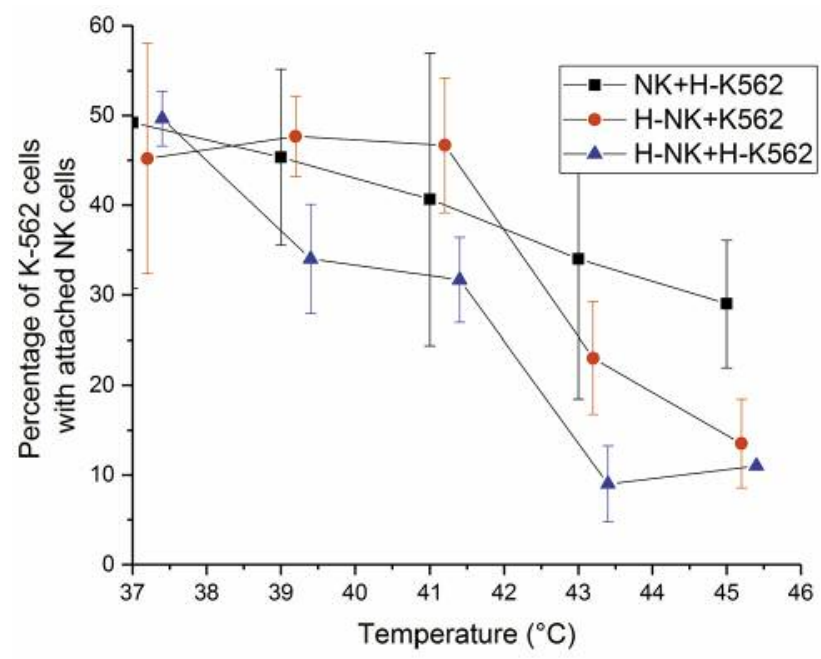

Figure 4. Effects of thermal treatment on the ability of effector natural killer (NK) cells to attach to non-heated and heated target $K-563$ (H-K-563) cells. Combinations of non-heated NK cells or heated-NK cells (H-NK) with non-heated $K-562$ cells or $H-K-562$ cells were assessed using temperatures ranging from 37 to $45^{\circ} \mathrm{C}$ for a heating time of $180 \mathrm{~min}$. The error bars represent the standard deviation of the experiments $(n=2-9)$.

ATP content of NK cells, initially with a 180 -min heating time (Figure 2). At temperatures from 37 to $41^{\circ} \mathrm{C}$, no change was observed. A dramatic and significant decrease in ATP level was observed between 41 and $42^{\circ} \mathrm{C}(p=0.020)$, followed by an insignificant reduction up to $45^{\circ} \mathrm{C}$.

In the subsequent experiments, the effects of heating times from 0 to $180 \mathrm{~min}$ at 41,42 and $45^{\circ} \mathrm{C}$ on the ATP level of NK cells were examined (Figure 3 ). At $41^{\circ} \mathrm{C}$, no differences in ATP level between $41^{\circ} \mathrm{C}$ and the $37^{\circ} \mathrm{C}$ control were observed at various heating times. A temperature of $42^{\circ} \mathrm{C}$ caused significantly $(p=0.048)$ greater reduction of ATP than at $41^{\circ} \mathrm{C}$. The effects of $42^{\circ} \mathrm{C}$ and $45^{\circ} \mathrm{C}$ were practically identical $(p>0.999)$.

The effects of thermal treatment on ATP/ADP metabolism of NK cells. To explore how heating affects ATP/ADP metabolism, we incubated $\mathrm{NK}$ cells at $42^{\circ} \mathrm{C}$ for $0,30,60$ and $120 \mathrm{~min}$. The ATP and ADP contents of the NK cells were measured. Both ATP and ADP levels decreased with increasing heating times. However, the decreases in ATP and ADP contents were not significant $(p=0.601$ and 0.831 , respectively). The ATP/ADP ratio did not change significantly $(p=0.714)$ at any of the time points examined. These results indicate that ATP production by the NK cells decreased only insignificantly at $42^{\circ} \mathrm{C}$ for incubation times from 0 to $120 \mathrm{~min}$ in the time range used.
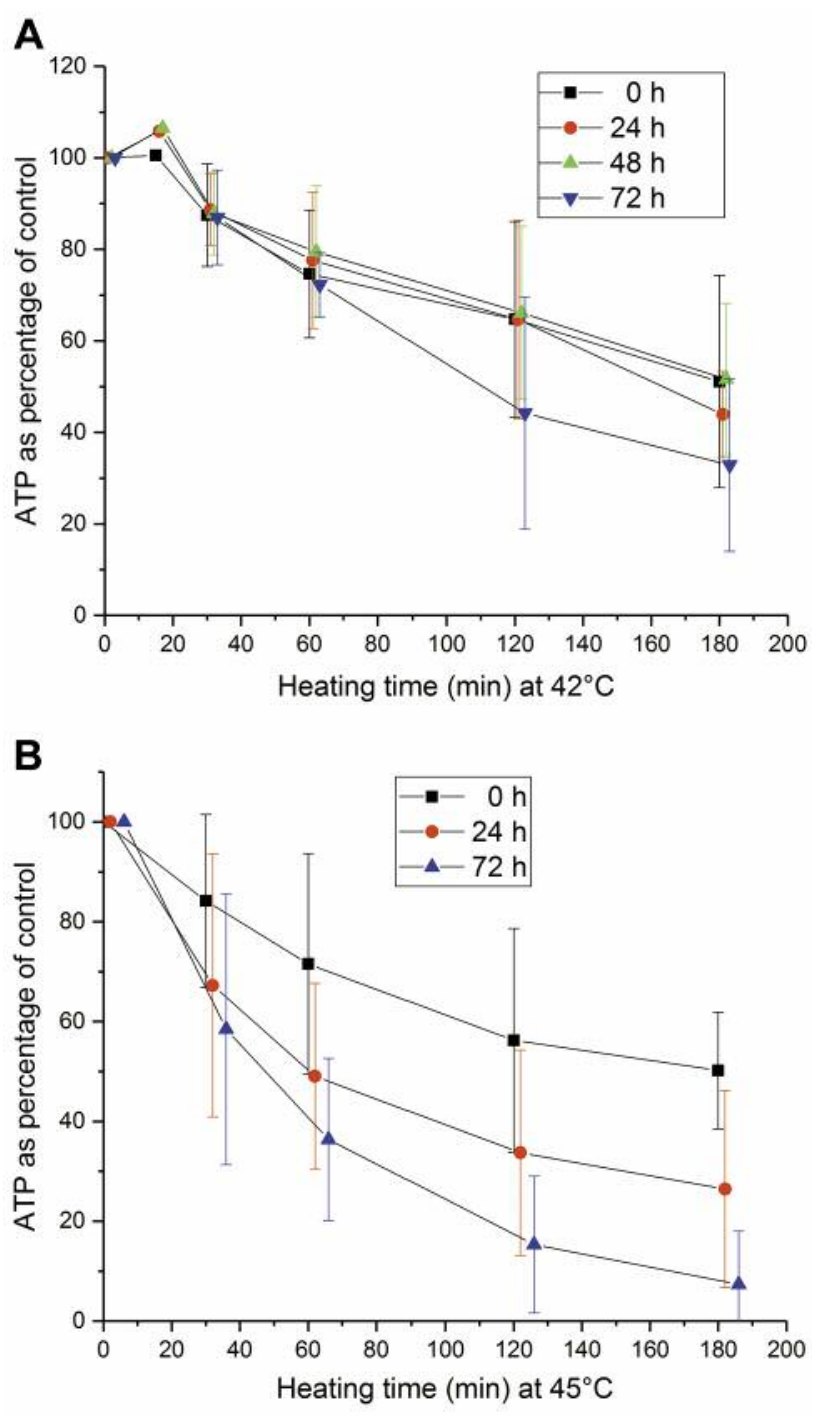

Figure 5. Recovery of adenosine triphosphate (ATP) content of natural killer (NK) cells from heating at $42^{\circ} \mathrm{C}(\mathrm{A})$ and $45^{\circ} \mathrm{C}(\mathrm{B})$ for $0,30,60$, 90,120 and $180 \mathrm{~min}$. The recovery time ranged from 0 to $72 \mathrm{~h}$ at $37^{\circ} \mathrm{C}$. The error bars represent the standard deviation of the experiments $(n=2-6)$.

Attachment of NK cells to target $K-562$ cells under different thermal conditions. To determine the effect of thermal treatment on attachment of effector NK cells to target K-562 cells, we heated NK cells and K-562 cells at temperatures from 37 to $45^{\circ} \mathrm{C}$ for $180 \mathrm{~min}$. Heated and non-heated NK and K-562 cells were combined and the attachment of K-562 cells with effector NK cells (rosettes) was calculated, and the results are expressed as a percentage of the corresponding non-heated control K-562 cells (Figure 4).

The percentages of rosettes of all combinations differed significantly from each other $(p<0.001)$. The number of 


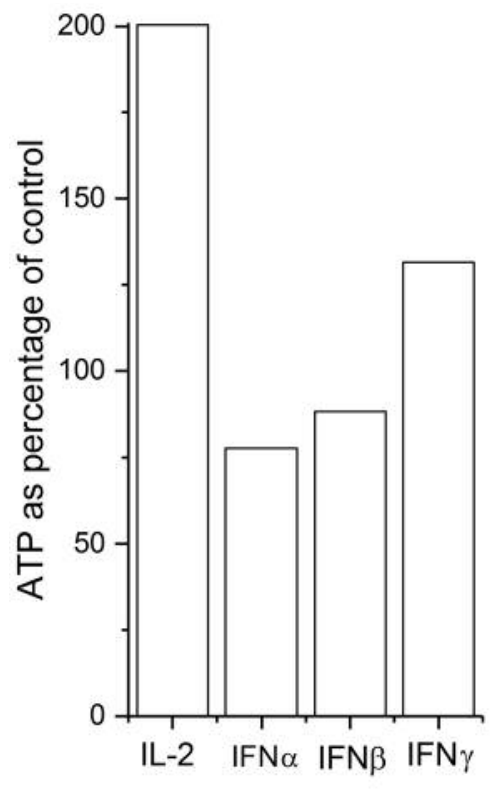

Figure 6. The effects of interleukin-2 (IL-2), interferon (IFN) $\alpha,-\beta$ and $-\gamma$ on adenosine triphosphate (ATP) levels of heated NK cells. The cells were treated for $2 \mathrm{~h}$ at $42^{\circ} \mathrm{C}$ and then incubated at $37^{\circ} \mathrm{C}$ for $72 \mathrm{~h}$ with $450 \mathrm{U} / \mathrm{ml} \mathrm{IL-2}$ or 1,000 U/ml IFNa, $-\beta$ or $-\gamma$. The ATP level was then measured. The results of a representative experiment are presented.

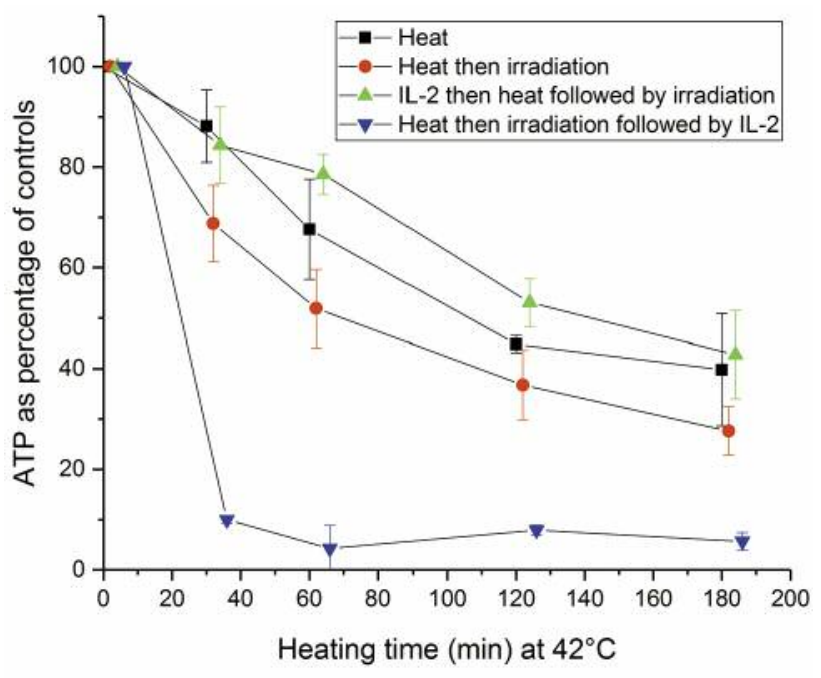

Figure 8. The effect of interleukin-2 (IL-2) on adenosine triphosphate (ATP) levels of heated and irradiated natural killer (NK) cells. The ATP content of the NK cells was measured after: thermal treatment alone for different durations at $42^{\circ} \mathrm{C}$; the same thermal treatment followed by irradiation at $20 \mathrm{~Gy} ; 100 \mathrm{U} / \mathrm{ml} \mathrm{IL-2}$ before heating then irradiation; and heating followed by irradiation then IL-2. The error bars represent the standard deviation of the experiments $(n=4)$. IL-2 applied before heat followed by irradiation reduced significantly more ATP damages than applied after heating and then irradiation $(p<0.001)$.

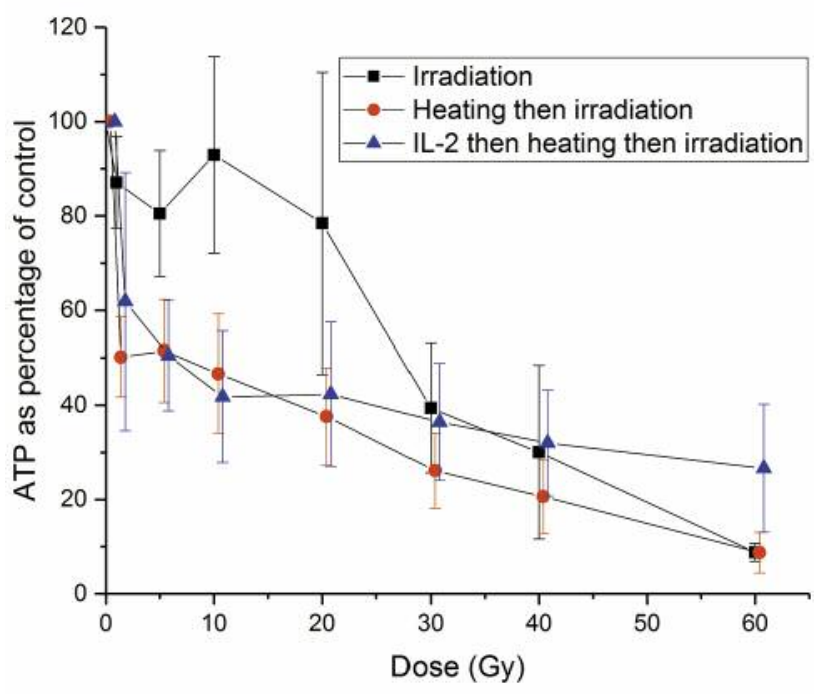

Figure 9. Adenosine triphosphate (ATP) content of natural killer (NK) cells after different doses of irradiation alone, irradiation preceded by heating at $42^{\circ} \mathrm{C}$ for $60 \mathrm{~min}$, and $100 \mathrm{U} / \mathrm{ml} \mathrm{IL}-2$ for $120 \mathrm{~h}$ before heating and irradiation. The error bars represent the standard deviation of the experiments $(n=4)$. IL-2 significantly reduced the damage to ATP level caused by heating followed by irradiation $(p<0.001)$. 
rosettes of the combination of non-heated NK cells with heated K-562 cells decreased linearly with increasing temperatures. Thus, heating target K-562 cells did not make them more attractive to effector NK cells. The combinations of heated NK cells with non-heated and heated K-562 cells demonstrated a substantial decrease in cell attachment between 41 and $43^{\circ} \mathrm{C}$. Heating both effector and target cells reduced the percentage of rosettes most effectively.

Recovery of ATP pool of heated NK cells. NK cells were incubated at 42 and $45^{\circ} \mathrm{C}$ for different times from 0 to 180 min and further incubated at $37^{\circ} \mathrm{C}$ for 0 to $72 \mathrm{~h}$ (Figure $5 \mathrm{~A}$ and $\mathrm{B})$. No recovery of ATP content in the NK cells was observed. The intracellular ATP content decreased as a function of heating temperature and time as well as recovery time.

The effects of IL-2 and IFN $\alpha, \beta$ and $\gamma$ on recovery of ATP content of thermally treated NK cells. The NK cells demonstrated no recovery from thermal treatments at $42^{\circ} \mathrm{C}$ or higher temperatures. To restore the ATP level, we first heated the NK cells at temperatures ranging from 40 to $45^{\circ} \mathrm{C}$ for 0 to $3 \mathrm{~h}$. We then incubated the cells at $37^{\circ} \mathrm{C}$ with 450 $\mathrm{U} / \mathrm{ml}$ IL- 2 or $1,000 \mathrm{U} / \mathrm{ml}$ IFN $\alpha,-\beta$ or $-\gamma$ for $72 \mathrm{~h}$. The results of a representative study at $42^{\circ} \mathrm{C}$ for $2 \mathrm{~h}$ heating time are presented in Figure 6. IL-2 elevated the ATP level by approximately $200 \%$ of that of controls at $37^{\circ} \mathrm{C}$. IFN $\gamma$ had a slight effect, whereas IFN $\alpha$ and $-\beta$ together with hyperthermia reduced the ATP level.

The effects of hyperthermia and irradiation on ATP level of $N K$ cells. In the subsequent experiments, the effects of different heating times in combination with fixed-dose irradiation were explored. The $\mathrm{NK}$ cells were treated in three different ways. They were heated at $42^{\circ} \mathrm{C}$ for 0 to $180 \mathrm{~min}$ or first heated as described and then irradiated with $20 \mathrm{~Gy}$, or first irradiated and then heated. The ATP content of NK cells was measured and expressed as a percentage that of the controls (Figure 7).

The ATP values of NK cells treated by these three modalities differed significantly from each other $(p<0.001)$. Heating alone was less damaging to the ATP content of the NK cells than the combination treatment. The combination of irradiation then heating reduced the ATP levels more than heating followed by irradiation $(p<0.001)$.

Role of IL-2 in restoring the ATP content of thermal-treated and irradiated NK cells. We previously demonstrated that IL-2 can restore NK cell cytotoxicity damaged by irradiation (32). In this study, we showed that IL-2 also elevated the ATP level of heated NK cells. We investigated whether IL-2 could also restore the ATP level of NK cells treated with combinations of heat and irradiation. The NK cells were exposed to four different conditions in order to observe the effects of heat only, heat then irradiation, IL-2 before heat followed by irradiation, and IL-2 after heat followed by irradiation at $42^{\circ} \mathrm{C}$.

Heating at $42^{\circ} \mathrm{C}$ ranged from 0 to $180 \mathrm{~min}$, the IL-2 concentration was $100 \mathrm{U} / \mathrm{ml}$ and the incubation time $120 \mathrm{~h}$, and the irradiation dose was 20 Gy (Figure 8). The ATP levels in NK cells of all combinations were significantly different from each other $(p<0.001)$. IL-2 pretreatment abolished the damaging effects of heating and irradiation. However, when IL-2 was applied after the combination of heating and irradiation, the ATP level was significantly lower than those of all other variations.

To further investigate the recovery of ATP level after the combination of irradiation and heat, we added IL- 2 before exposure to the combination, and there was a time interval from 0 to $6 \mathrm{~h}$ between irradiation and heating. No additional effect was observed. The results were similar when the NK cells were irradiated first with time intervals from 0 to $6 \mathrm{~h}$ before IL-2 incubation.

Effects of hyperthermia and different irradiation doses on the ATP content of NK cells. To determine the effect of irradiation on ATP levels of NK cells treated with a combination of IL-2, heating and irradiation, we performed the following experiments: Irradiation with doses from 0 to $60 \mathrm{~Gy}$ alone; thermal treatment at $42^{\circ} \mathrm{C}$ for $60 \mathrm{~min}$ followed by irradiation; incubation with IL-2 $100 \mathrm{U} / \mathrm{ml}$ for $120 \mathrm{~h}$ followed by heating and irradiation (Figure 9). The effects of these treatments on the ATP level were significantly different from each other $(p<0.001)$. Irradiation alone was less damaging to the ATP level than thermal treatment and irradiation $(p<0.001)$. IL-2 significantly reduced $(p<0.001)$ the decrease of ATP caused by the combination of heating and irradiation depending on the irradiation dose. This effect was observed even at a dose of $60 \mathrm{~Gy}$.

\section{Discussion}

In an earlier study, we investigated the effects of hyperthermia and irradiation on NK cell cytotoxicity (29). In this study, we concentrated on the intracellular ATP content of NK cells treated by hyperthermia and irradiation. ATP is the major source of energy in living cells (35-37) and the ATP level is a determinant of manifestation of cell death. The ATP pool of a cell directs the death signalling pathways to activation of apoptotic signal transduction or induction of necrotic cell death. Both types of cell death can be observed at the same time (28).

We found that the ATP level of the NK cells was stable from 37 to $41^{\circ} \mathrm{C}$ and then dropped dramatically at $42^{\circ} \mathrm{C}$. This is in accordance with findings of Power et al. (27) and Jonsson et al. (38) 
In our study, no significant recovery of ATP level was detected with any temperature-heating time combination when heating from 42 to $45^{\circ} \mathrm{C}$, followed by recovery at $37^{\circ} \mathrm{C}$ for up to $72 \mathrm{~h}$. Our results confirmed the findings of Jonsson et al. (38) and Kjellen et al. (39). They previously demonstrated that non-recovery is related to the nicotinamide adenine dinucleotide $\left(\mathrm{NAD}^{+}\right)$pool.

The ATP/ADP ratio reflects ATP production and consumption. Both ATP and ADP pools decreased at $42^{\circ} \mathrm{C}$ during the heating times used. However, the ATP/ADP ratio decreased only insignificantly and remained stable. These findings indicate that ATP production was affected and not consumption. The same phenomenon was reported by Jonsson et al. (38).

Thermal treatments of target cancer cells at high temperatures may destroy their cell membranes or alter membranous structures, thus releasing antigenic structures. This may increase the antigenic structures of target cells and make them more 'attractive', leading to an increased number of attached NK cells. We heated the target K-562 cells at temperatures ranging from $37^{\circ} \mathrm{C}$ to $45^{\circ} \mathrm{C}$ and then incubated the target cells with the NK cells at $37^{\circ} \mathrm{C}$. In this setting, a decrease in the number of attached cells was detected. Thus, increasing temperature did not augment the antigenicity of the target K-562 cells to effector NK cells.

Effects of thermal treatment on tumor antigenicity and recognition by immune effector cells are complex and dependent on several factors, including the thermal dose, the thermosensitivity of tumor cell type and the model system used, as reviewed by Milani and Noessner (40). The activation or inhibition of NK cells is a balancing act of several signals including loss of MHC class I by tumor cells and expression of ligands for activating receptors expressed by NK cells such is MHC class I polypeptide-related sequence A/B (MICA/B) and heat-shock proteins. Heatshock effects on NK-mediated lysis are independent of MHC class I peptide complexes. The results published to date are conflicting (40).

We initially applied three different methods to measure death of heated and irradiated NK cells: ATP measurements, trypan blue exclusion and propidium iodide staining. They all reflect different aspects of cell death. Trypan blue exclusion and propidium iodide methods are based on the principle that living cells possess intact cell membranes that exclude certain dyes, such as trypan blue (41) and propidium iodide (42). We detected no significant differences among the methods used. ATP was selected for this study because it was easy to use, reliable and reproducible.

The ATP level of the NK cells did not recover from hyperthermic treatments. Therefore, we used IL-2 and IFN $\alpha$, $-\beta$ and $-\gamma$ to enhance the ATP recovery. At $42^{\circ} \mathrm{C}$, IL-2 increased the ATP level of the NK cells significantly over that of controls at $37^{\circ} \mathrm{C}$. IFN $\gamma$ showed some activity, whereas
IFN $\alpha$ and $-\beta$ reduced the ATP level. According to the literature, these are novel findings.

Hyperthermia and radiation have been combined in cancer treatment for decades $(13,15,43)$. The underlying rationale is that radiation resistance of tumour cells is related to the capacity of cells to repair sublethal DNA radiation damage, and hyperthermia inhibits the function of proteins involved in DNA replication. Thus, hyperthermic treatment after irradiation results in higher inhibition of DNA repair than if it is administered before radiation $(44,45)$. Therefore, we studied the effects of exposure to $42^{\circ} \mathrm{C}$ for 0 to $180 \mathrm{~min}$ and the combined effects of radiation and hyperthermia, as well as hyperthermia and radiation and hyperthermia alone on the ATP level of NK cells. The combination that reduced the ATP content most was that of radiation administered first and then hyperthermic treatment. The next most effective combination was hyperthermia administered first and then irradiation, while the least damaging treatment was hyperthermia alone. Our results are consistent with results of Raaphorst previous publications (45). Our experiments also confirmed the results of Jonsson et al. (38) and Kjellén et al. (39) on mononuclear leucocytes. They demonstrated that hyperthermia alone reduces the ATP pool and DNA repair. The biosynthesis of ATP and $\mathrm{NAD}^{+}$are coupled to each other via mitochondria. Hyperthermia damages the function of mitochondria. Thus, $\mathrm{NAD}^{+}$cannot be regenerated even after mild hyperthermia at $42.5^{\circ} \mathrm{C}$. However, NAD ${ }^{+}$pools can be regenerated after irradiation. The researchers hypothesised that hyperthermia radiosensitises cells because it prevents normal cellular regeneration of $\mathrm{NAD}^{+}$, which, in turn, limits adenosine diphosphoribosyl transferase via cosubstrate limitations. Thus, normal repair of DNA is impaired, resulting in increased cytotoxicity $(38,39)$.

In vivo, the combination of radiotherapy and hyperthermia has been applied for decades (46). For whole-body hyperthermic therapy, temperatures from 38 to $42^{\circ} \mathrm{C}$ are used, and 40 to $45^{\circ} \mathrm{C}$ temperatures are used for locoregional treatments. The heating times vary from 120 to $720 \mathrm{~min}$, including times necessary to reach the steady state (47). The usual daily radiation dose of 2 Gy does not alone affect the ATP content of NK cells. Based on the results of this study, we concluded that these treatments combined significantly reduced the ATP content of the NK cells. However, in vitro and in vivo cytokines such as IL-2 can restore the ATP pool, particularly after the combination of hyperthermia and irradiation. Thus, the intracellular ATP content of NK cells is not a limiting factor for hyperthermic treatment with or without irradiation.

\section{Acknowledgements}

The Authors acknowledge Eija Isolehto for excellent technical assistance, Tuomo Timonen M.D., Ph.D. for fruitful discussions and Heini Hautala, M.Sc. for statistical assistance. 


\section{References}

1 Cheng M, Chen Y, Xiao W, Sun R and Tian Z: NK cell-based immunotherapy for malignant diseases. Cell Mol Immunol 10: 230-252, 2013.

2 Shanker A and Marincola FM: Cooperativity of adaptive and innate immunity: implications for cancer therapy. Cancer Immunol Immunother 60: 1061-1074, 2011.

3 Vivier E, Ugolini S, Blaise D, Chabannon C and Brossay L: Targeting natural killer cells and natural killer $\mathrm{T}$ cells in cancer. Nat Rev Immunol 12: 239-252, 2012.

4 Freud AG and Caligiuri MA: Human natural killer cell development. Immunol Rev 214: 56-72, 2006.

5 Smyth MJ, Hayakawa Y, Takeda K and Yagita H: New aspects of natural-killer-cell surveillance and therapy of cancer. Nat Rev Cancer 2: 850-861, 2002.

6 McDowell KA, Hank JA, DeSantes KB, Capitini CM, Otto M and Sondel PM: NK cell-based immunotherapies in Pediatric Oncology. J Pediatr Hematol Oncol 37: 79-93, 2015.

7 van der Zee J, Gonzalez Gonzalez D, van Rhoon GC, van Dijk JD, van Putten WL and Hart AA: Comparison of radiotherapy alone with radiotherapy plus hyperthermia in locally advanced pelvic tumours: a prospective, randomised, multicentre trial. Dutch Deep Hyperthermia Group. Lancet 355: 1119-1125, 2000

8 Loggie BW, Fleming RA, McQuellon RP, Russell GB and Geisinger KR: Cytoreductive surgery with intraperitoneal hyperthermic chemotherapy for disseminated peritoneal cancer of gastrointestinal origin. Am Surg 66: 561-568, 2000.

9 Zarcone D, Tilden AB, Lane VG and Grossi CE: Radiation sensitivity of resting and activated nonspecific cytotoxic cells of T lineage and NK lineage. Blood 73: 1615-1621, 1989.

10 Rana R, Vitale M, Mazzotti G, Manzoli L and Papa S: Radiosensitivity of human natural killer cells: binding and cytotoxic activities of natural killer cell subsets. Radiat Res 124: 96, 1990.

11 Zwischenberger JB, Vertrees RA, Bedell EA, McQuitty CK, Chernin JM and Woodson LC: Percutaneous venovenous perfusion-induced systemic hyperthermia for lung cancer: a phase I safety study. Ann Thorac Surg 77: 1916-1924; discussion $1925,2004$.

12 Gabriele P, Orecchia R, Ragona R, Tseroni V and Sannazzari GL: Hyperthermia alone in the treatment of recurrences of malignant tumors. Experience with 60 lesions. Cancer 66: 21912195, 1990.

13 Kim JY, Son YO, Park SW, Bae JH, Chung JS, Kim HH, Chung BS, Kim SH and Kang CD: Increase of NKG2D ligands and sensitivity to NK cell-mediated cytotoxicity of tumor cells by heat shock and ionizing radiation. Exp Mol Med 38: 474-484, 2006.

14 Datta NR, Ordonez SG, Gaipl US, Paulides MM, Crezee H, Gellermann J, Marder D, Puric E and Bodis S: Local hyperthermia combined with radiotherapy and-/or chemotherapy: Recent advances and promises for the future. Cancer Treat Rev 41: 742-753, 2015.

15 Datta NR, Rogers S, Ordonez SG, Puric E and Bodis S: Hyperthermia and radiotherapy in the management of head and neck cancers: A systematic review and meta-analysis. Int J Hyperthermia 32: 31-40, 2016.

16 Axelrod YK and Diringer MN: Temperature management in acute neurologic disorders. Neurol Clin 26: 585-603, xi, 2008.
17 Laupland KB: Fever in the critically ill medical patient. Crit Care Med 37: S273-278, 2009.

18 Lepock JR, Frey HE and Ritchie KP: Protein denaturation in intact hepatocytes and isolated cellular organelles during heat shock. J Cell Biol 122: 1267-1276, 1993.

19 Roti Roti JL: Cellular responses to hyperthermia $\left(40-46^{\circ} \mathrm{C}\right)$ : Cell killing and molecular events. Int J Hyperthermia 24: 3-15, 2008.

20 Zanker KS and Lange J: Whole body hyperthermia and natural killer cell activity. Lancet 1: 1079-1080, 1982.

21 Kappel M, Stadeager C, Tvede N, Galbo H and Pedersen BK: Effects of in vivo hyperthermia on natural killer cell activity, in vitro proliferative responses and blood mononuclear cell subpopulations. Clin Exp Immunol 84: 175-180, 1991.

22 Nurmi T, Uhari $M$ and Kouvalainen K: Temperature and natural killer cell activity. Lancet 1: 516-517, 1982.

23 Azocar J, Yunis EJ and Essex M: Sensitivity of human natural killer cells to hyperthermia. Lancet 1: 16-17, 1982.

24 Onsrud M: Effect of hyperthermia on human natural killer cells. Recent Results Cancer Res 109: 50-56, 1988.

25 Jonsson GG, Eriksson $G$ and Pero RW: Influence of hyperthermia and gamma radiation on ADP-ribosyl transferase, $\mathrm{NAD}^{+}$, and ATP pools in human mononuclear leukocytes. Radiat Res 102: 241-253, 1985.

26 Creissen D and Shall S: Regulation of DNA ligase activity by poly(ADP-ribose). Nature 296: 271-272, 1982.

27 Power A, Pearson N, Pham T, Cheung C, Phillips A and Hickey A: Uncoupling of oxidative phosphorylation and ATP synthase reversal within the hyperthermic heart. Physiol Rep 2: 9e12138, 2014.

28 Eguchi Y, Shimizu S and Tsujimoto Y: Intracellular ATP levels determine cell death fate by apoptosis or necrosis. Cancer Res 57: 1835-1840, 1997.

29 Hietanen T, Kapanen M and Kellokumpu-Lehtinen PL: Restoring natural killer cell cytotoxicity after hyperthermia alone or combined with radiotherapy. Anticancer Res 36: 555-563, 2016.

30 Hietanen T, Pitkanen M, Kapanen M and Kellokumpu-Lehtinen PL: Post-irradiation viability and cytotoxicity of natural killer cells isolated from human peripheral blood using different methods. Int J Radiat Biol 92: 71-79, 2016.

31 Lozzio $\mathrm{CB}$ and Lozzio BB: Human chronic myelogenous leukemia cell-line with positive Philadelphia chromosome. Blood 45: 321-334, 1975.

32 Hietanen T, Kellokumpu-Lehtinen P and Pitkanen M: Action of recombinant interferons and interleukin 2 in modulating radiation effects on viability and cytotoxicity of large granular lymphocytes. Int J Radiat Biol 67: 119-126, 1995.

33 Hietanen T, Pitkanen M, Kapanen M and Kellokumpu-Lehtinen PL: Effects of single and fractionated irradiation on natural killer cell populations: radiobiological characteristics of viability and cytotoxicity in vitro. Anticancer Res 35: 5193-5200, 2015.

34 Timonen T, Ortaldo JR and Herberman RB: Characteristics of human large granular lymphocytes and relationship to natural killer and K cells. J Exp Med 153: 569-582, 1981.

35 Okada S: Cells. In: Radiation Biochemistry (Altman KI, Gerber GB and Okada S (eds.). New York and London, Academic Press, pp. 247, 1970.

36 Bhatt AN, Chauhan A, Khanna S, Rai Y, Singh S, Soni R, Kalra $\mathrm{N}$ and Dwarakanath BS: Transient elevation of glycolysis confers radio-resistance by facilitating DNA repair in cells. BMC Cancer 15: 335-015-1368-9, 2015. 
37 Lu CL, Qin L, Liu HC, Candas D, Fan M and Li JJ: Tumor cells switch to mitochondrial oxidative phosphorylation under radiation via mTOR-mediated hexokinase II inhibition-a Warburg-reversing effect. PLoS One 10: e0121046, 2015.

38 Jonsson GG, Eriksson G and Pero RW: Effects of gamma radiation and hyperthermia on DNA repair synthesis and the level of $\mathrm{NAD}^{+}$in cultured human mononuclear leukocytes. Radiat Res 97: 97-107, 1984.

39 Kjellen E, Jonsson GG, Pero RW and Christensson PI: Effects of hyperthermia and nicotinamide on DNA repair synthesis, ADP-ribosyl transferase activity, $\mathrm{NAD}^{+}$and ATP pools, and cytotoxicity in gamma-irradiated human mononuclear leukocytes. Int J Radiat Biol Relat Stud Phys Chem Med 49: 151-162, 1986.

40 Milani V and Noessner E: Effects of thermal stress on tumor antigenicity and recognition by immune effector cells. Cancer Immunol Immunother 55: 312-319, 2006.

41 Strober W: Trypan blue exclusion test of cell viability. Curr Protoc Immunol 111: A3.B.1-3, 2015.

42 Crowley LC, Scott AP, Marfell BJ, Boughaba JA, Chojnowski $\mathrm{G}$ and Waterhouse NJ: Measuring cell death by propidium iodide uptake and flow cytometry. Cold Spring Harb Protoc 2016: pdb.prot087163, 2016.
43 Field SB: 1985 Douglas Lea Memorial Lecture. Hyperthermia in the treatment of cancer. Phys Med Biol 32: 789-811, 1987.

44 Lauber K, Brix N, Ernst A, Hennel R, Krombach J, Anders H and Belka C: Targeting the heat shock response in combination with radiotherapy: Sensitizing cancer cells to irradiation-induced cell death and heating up their immunogenicity. Cancer Lett 368 : 209-229, 2015.

45 Raaphorst GP: Recovery of sublethal radiation damage and its inhibition by hyperthermia in normal and transformed mouse cells. Int J Radiat Oncol Biol Phys 22: 1035-1041, 1992.

46 Field SB and Bleehen NM: Hyperthermia in the treatment of cancer. Cancer Treat Rev 6: 63-94, 1979.

47 Szasz A: Hyperthermia results and challenges. In: Oncothermia: Principles and Practices. Andraz Szasz, Nora Szazs and Oliver Szazs (ed.). Springer Science+Business Media B.V., pp. 17, 2011.

Received November 1, 2017

Revised November 27, 2017

Accepted November 30, 2017 